\title{
Új mutató a hazai egészségügy eredményességének mérésére: az egészségügyi ellátás hozzáférhetősége és minősége index
}

\author{
New indicator for measuring the performance of the Hungarian \\ health system: Healthcare Access and Quality Index
}

Szerzők: Vitrai Józsefa® $\bowtie$, Bakacs Mártab

a: Emberi Erőforrások Minisztériuma, b: Országos Gyógyszerészeti és

Élelmezés-egészségügyi Intézet

Beküldve: 2018. 08. 26.

doi: 10.24365/ef.v59i4.349

\begin{abstract}
Összefoglaló: A Global Burden of Disease Study (Globális Betegségteher Vizsgálat) nemrég hozta nyilvánosságra azt a tanulmányát, melyben a világ országai, így hazánk egészségügyi ellátásának hozzáférhetőségét és minőségét elemezte. Az egészségügy eredményességének vizsgálatára a - többféle szempontból korrigált - megelőzhető és elkerülhető halálozás alapján képzett új indexet alkalmaztak. Ennek eredményeként a magyar egészségügy a világrangsor 40 . helyére került. Leginkább a keringési és a rosszindulatú daganatos betegségek megelőzése és gyógyítása területén lenne Magyarországnak javítanivalója. Az elemzések rávilágítottak arra is, hogy a magyar egészségügy teljesítményének növeléséhez a rendszer elsődleges megelőzést előtérbe helyező átstrukturálása mellett, az egészségügyi kiadások növelése, illetve a magánkiadások részarányának csökkentése is hozzájárulna.
\end{abstract}

Kulcsszavak: egészségügyi rendszer; teljesítmény

Summary: The Global Burden of Disease Study recently published the results of its performance analysis on the health care access and quality in 195 countries including Hungary. To assess the performance of the health systems a new index based on preventable and amenable mortality corrected to different factors was applied. The Hungarian health system is on the 40th place in the global list developed on the basis of this index. There is a great space to improve the performance in prevention and care of diseases of the cardiovascular system and cancers in Hungary. Beyond restructuring the health system in Hungary with the main focus on primary prevention, the analysis provided additional pieces of evidences, namely the increase of the health expenditure and the decrease of the portion of the out-of-pocket expenditure would also help to improve the performance of the health system.

Keywords: health system; performance

\section{BEVEZETÉS}

A Globális Betegségteher Vizsgálat (GBV) évről-évre újabb és újabb eredményekkel váltja ki az egészség monitorozásával foglalkozó szakemberek elismerését. ${ }^{1}$ A ma már világszerte 3000-nél több kutatót foglalkoztató projekt 2015-től évente nemcsak
195 országra, hanem egyre bővülő számban országrészekre is közöl becsléseket: 315 betegségre és 79 kockázati tényezőre vonatkozóan a halandóság mellett az elvesztett egészséges életévekre is (ELÉV, angolul: DALY), ami az „idő előtti” halálozás és a megromlott egészséggel leélt évek súlyozott összege. 2017 elején az egészségügyi szakpolitika 
értékeléséhez újabb mutatót vezettek be: az ellátás hozzáférhetősége és minősége indexet (Healthcare Access and Quality Index; magyar fordítás rövidítésével: EHMI). ${ }^{3} \mathrm{Az}$ alábbiakban röviden bemutatjuk az EHMI számításának módszertanát, és már a 2018-as újabb tanulmány alapján a Magyarországra vonatkozó eredményeket, valamint kitérünk az ellátás minőségének értékelését célzó hazai és külföldi hasonló kezdeményezésekre is. ${ }^{4}$

\section{AZ EHMI MÓDSZERTANA}

Nolte és McKee 2003-as közleménye nyomán szakmai körökben elfogadottá vált, hogy bizonyos betegségek okozta halálozások megfelelő népegészségügyi intézkedésekkel megelőzhetők, illetve időben nyújtott, adekvát orvosi ellátás igénybevételével elkerülhetők lennének. ${ }^{5}$ Például a tüdőrák okozta halálozás jórészt megelőzhető lenne, ha megfelelő népegészségügyi intézkedésekkel a dohányzást jelentősen visszaszorítanák, vagy a vakbélgyulladás következtében bekövetkező halálozás elkerülhető lenne, ha a beteg időben megfelelő operációban részesülne. Az Európai Unió egészségügyi rendszereinek eredményességét, múködtetésének hatásosságát az Eurostat is a két kutató vizsgálataira alapozva minősíti a megelőzhető és elkerülhető halálozás mutatóival. ${ }^{6}$ A GBV projektben, az újabb kutatások eredményei alapján némileg módosítva a Nolte és McKee által összeállított betegséglistát, minden vizsgált országra és országrészre, összesen 32 halálok figyelembe vételével becsülték meg a megelőzhető, illetve elkerülhető halálozást.'

A megelőzhető és elkerülhető halálozás ugyanakkor nem független a lakosság egészségi állapotát befolyásoló társadalmi-gazdasági tényezőktől. Közismert, hogy az alacsony jövedelműek gyakrabban dohányoznak, fogyasztanak túlzott mértékben alkoholt, és élnek egészségkárosító életkörülmények között. Így ha tisztán az egészségügyi rendszer eredményességét kívánjuk jellemezni, akkor célszerû a rajta kívüli hatásokat kiszűrni.

A GBV projektben az egészségügyi rendszeren kívüli tényezők hatásának kiszűréséhez több lépésben végeztek standardizálást a szakértők. Először a megelőzhető és elkerülhető halálozás betegséglistáján szereplő - nem rákbetegség okozta - halálozásokat az adott területre becsült egészségmagatartási és környezeti kockázatokra standardizálták. Ezzel az eljárással elérték, hogy az egyes területeken megfigyelt megelőzhető és elkerülhető halálozás közti eltérések függetlenek lettek például az ott élők étkezési, dohányzási és alkoholfogyasztási szokásaitól, környezetük szennyezettségétől.

Másodszor, a rákbetegség-gyógyítás eredményességének jellemzésére a rákhalálozást az adott évben regisztrált új rákbetegek számához, azaz az incidenciához viszonyították. Ezzel tulajdonképpen egyfajta túlélési arányt számoltak (pontosabban: az adott évben a rákbetegek milyen arányban nem élik túl a betegséget), így minősítve a rákbetegségek orvosi ellátásának eredményességét.

Harmadszor, annak érdekében, hogy az egészségügyi rendszerek eredményessége összehasonlítható legyen, életkorra és nemre is standardizálták a kockázatra, illetve a rákbetegségek esetében az incidienciára már standardizált halálozásokat. Erre a lépésre nyilvánvalóan azért volt szükség, mert a halálozás valószínűsége a nők és a férfiak különböző életkori csoportjaiban jelentősen eltérő.

A megelőzhető és elkerülhető halálokokra kapott standardizált adatokból fő́komponens-analízissel meghatározták az egyes halálokoknak az egészségügy eredményességében játszott súlyát. E súlyok figyelembevételével számították ki minden vizsgált országra és országrészre az EHMI-t 1990-től kezdődően 5 évente, illetve 2016-ra. Az EHMI-t úgy skálázták, hogy a 0 a legrosszabb, míg a legmagasabb 100-as érték a leginkább eredményes egészségügyi rendszert jelentette. A könnyebb értelmezhetőséget segíti az is, hogy az eredményeket az országok fejlettsége alapján képzett csoportonként is megadták.i

Az EHMI használhatóságának ellenőrzésére Pearson-féle korrelációs együtthatót számítottak az adott ország, terület EHMI-je és az egészségügyi rendszer hagyományos input és output jellemzői között. Így mérték a kapcsolatot a teljes egészségügyi kiadás, a kormányzati kiadások részaránya, az egészségügyi szakdolgozók száma, a kórházi ágyak

\footnotetext{
' Meg kell jegyezni, az Eurostat Nolte és McKee listáját ugyancsak módosította, így a megelőzhető és elkerülhető halálozás adatai számszerűleg nem összevethetők a GBV projektben számoltakkal.

ii A csoportosításhoz az ún. társadalmi-gazdasági indexet (Socio-demographic Index, SDI) használták, melyet az egy főre jutó átlagos jövedelem, az átlagos iskolázottsági szint és a teljes termékenységi arányszám alapján számítanak ki.
} 
1000 lakosra számított száma, a járóbeteg- és a kórházi ellátás igénybevétele és az EHMI között.

\section{EREDMÉNYEK}

\section{Az EHMI a világban és Magyarországon}

2016-ban a vizsgált 195 ország közül az európaiak, valamint Kanada, Japán, Ausztrália és Új-Zéland egészségügyi ellátása a legjobb 10\%-ba estek az EHMI-vel mérve. A legrosszabbak a Szaharától délre eső országok voltak. Magyarország a 40. helyen 82-es EHMI-t ért el, míg a Visegrádi országok EHMI értékei a következők voltak: Csehország 89, Szlovákia 83, Lengyelország 82. [1. táblázat] 1990-tól 2016-ig 186 országban nőtt az EHMI, átlagosan 16,8 ponttal. Magyarországon az egészségügy eredményessége az 1990-es 66,4-ről 15,7 ponttal javult.

Az egyes halálokokra külön-külön vizsgálva a hazai egészségügyi rendszer 2016-os eredményességét, komoly eltérések figyelhetők meg. A fertőző betegségek ellátása kiválónak, többségükben 100 pontosnak adódott, a legalacsonyabb, 91 pont a hasmenéssel járó fertőző betegségek (a GBV projektben: Diarrhoeal diseases) esetében volt. Jóval alacsonyabb, 72 pontos volt csupán az újszülötteket érintő betegségek (Neonatal disorders) ellátása.

A magyar egészségügyi rendszer teljesítménye a legrosszabbnak a keringési rendszer betegségei és a rosszindulatú daganatok megelőzése és gyógyítása területén bizonyult. A keringési betegségek esetében legkevesebb pontot, 40-et a magas vérnyomásos szívbetegségek (Hypertensive heart disease), 52-öt az iszkémiás szívbetegség (Ischaemic heart disease), legtöbbet, 61-et a reumás szívbetegségek (Rheumatic heart disease) ellátása kapta.

A rosszindulatú daganatos betegségek közül legalacsonyabbra, 55-re a nem-melanoma típusú bőrrák (Non-Melanoma skin cancer, SCC), 60-ra a méhnyakrák (Cervical cancer), 62-re a Hodgkinlimfóma (Hodgkin's lymphoma), legmagasabbra, 74-re a leukémia (Leukaemia), 80-ra a méhtestrák (Uterine cancer) ellátását értékelték.
Alacsonyra értékelték továbbá a gyomor és nyombél gyulladásos betegségei (Peptic ulcer disease; 55), a veleszületett keringési rendszer betegségei (Congenital heart anomalies; 63), és magasra a krónikus légzőrendszeri betegségek (Chronic respiratory diseases; 94) valamint a vakbélgyulladás (Appendicitis; 97) ellátását.

Az EHMI és az egészségügy más jellemzői közötti öszszefüggések

$A z E H M I$ értékeinek az egészségügyi input, illetve output mutatókkal való összefüggését vizsgálva kitűnt, hogy az egy főre jutó egészségügyi kiadás igen jól korrelált az EHMI-vel $(r=0,94)$. Nagy hatékonysági (ráfordítás/eredményesség) különbségek voltak azonban megfigyelhetők az országok között még a magas EHMI tartományban is. [1. ábra]

Bár az USA, például Csehországgal azonos, 89-es EHMI-t ért el, annál közel 4-szer többet fordított az egészségügyre. A magyar egészségügy hatékonyságának javítási lehetőségét jelzi, hogy Lengyelország hazánknál 10\%-kal kevesebbet költött egészségügyre 2016-ban, mégis Magyarországgal megegyező EHMI értéket kapott.iii

Az egészségügyi kiadásoknak a kormányzati költségvetésben való részaránya $(r=0,93)$ és az egy főre jutó magánkiadások $(r=0,85)$ is erős összefüggést mutattak az EHMI-vel. Igaz, a magánkiadásoknak a teljes egészségügyi kiadásokon belüli részaránya gyenge negatív korrelációt $(r=-0,31)$ mutatott, azaz a nagyobb arányú „zsebből” fizetett kiadás inkább csökkentette az EHMI értékét. Az országok társadalmi-gazdasági fejlettségét jelző SDI korrelációja ugyancsak magas volt $(r=0,94)$.

Az egészségügy teljesítményét jelző inputok közül az orvosok, nővérek és szülészek 1000 lakosra vetített száma jelentősebb $(r=0,79)$, míg a kórházi ágyak száma ennél gyengébb $(r=0,63)$ összefüggést mutatott az EHMI-vel. Az outputok, azaz a járó-, illetve fekvőbeteg-ellátás közepes erősségű korrelációt mutattak ( $r=0,56$ és $r=0,64)$ az index-szel.

\footnotetext{
iii 2016-ban a teljes egészségügyi kiadás egy főre USD PPP-ben mérve az USA-ban 9823, Csehországban 2482, Lengyelországban 1784, Magyarországon 1967 volt. Forrás: OECD.Stat https://stats.oecd.org/viewhtml.aspx?datasetcode=SHA\&lang=en\# (elérve: 2018. 08. 16.)
} 
Iceland [1]

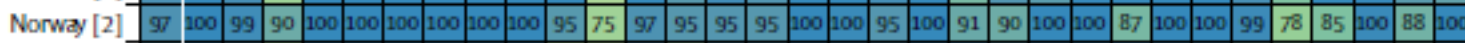

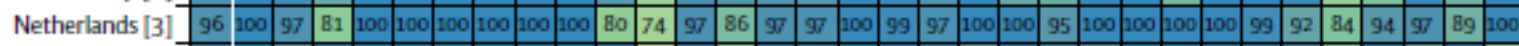

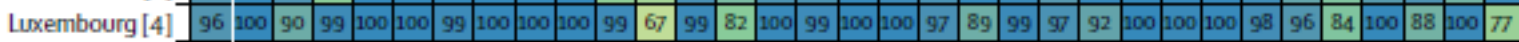

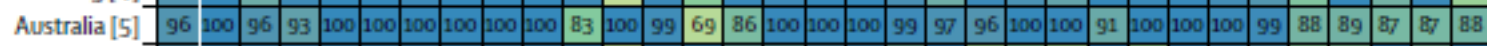

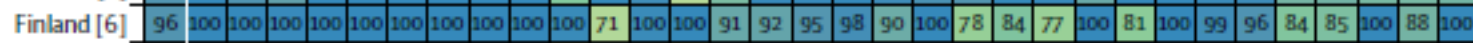

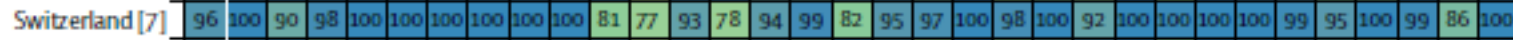

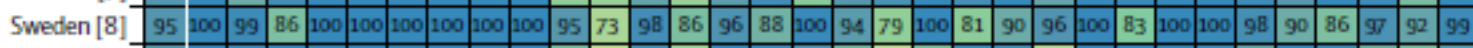

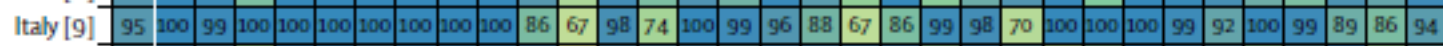

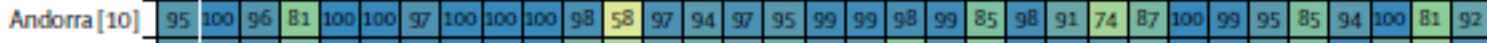

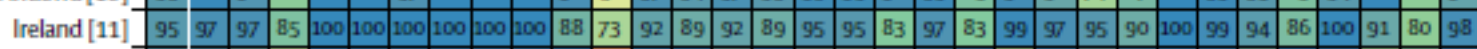

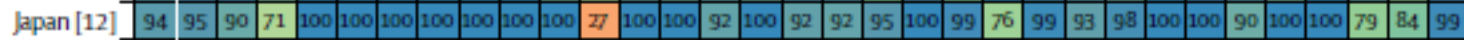

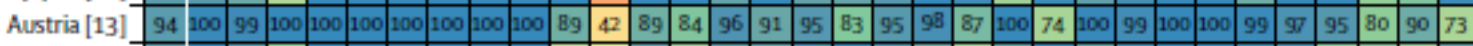

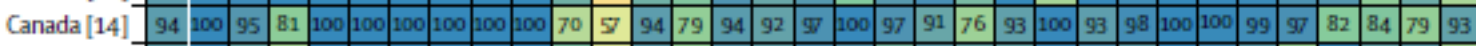

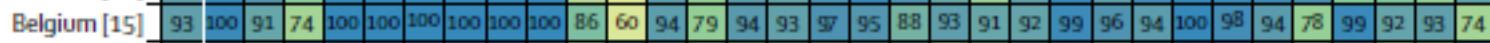

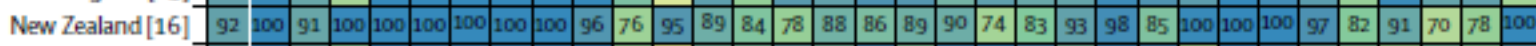

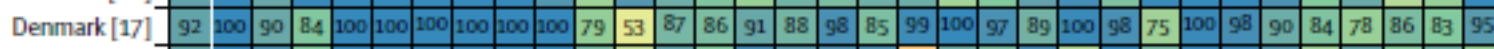

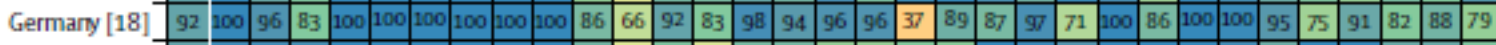
Spain [19]

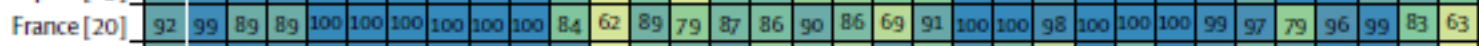

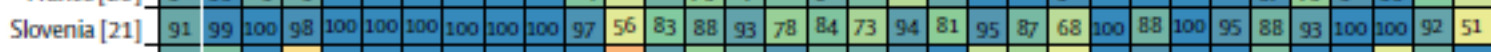
Singapore [22]

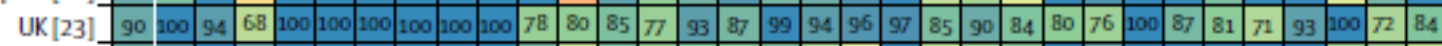

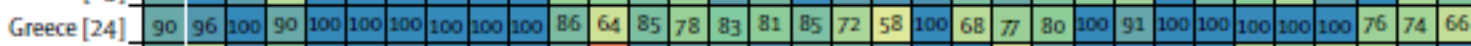

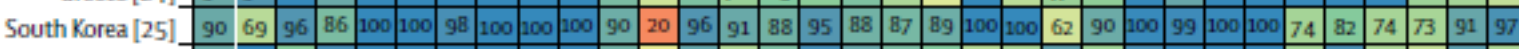

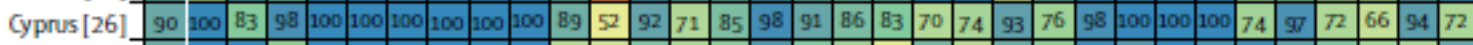

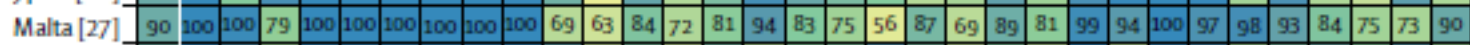
\begin{tabular}{|c|c|c|c|c|c|c|c|c|c|c|c|c|c|c|c|c|c|c|c|c|c|c|c|c|c|c|c|c|c|c|c|c|c|c|c|}
\hline Gech Republic [28] & 89 & 100 & 96 & 77 & 100 & 100 & 100 & 100 & 100 & 100 & 92 & 67 & 85 & 67 & 87 & 72 & 83 & 84 & 95 & 86 & 68 & 84 & 70 & 100 & 71 & 100 & 97 & 78 & 86 & 90 & 83 & 94 & 79 \\
\hline
\end{tabular}

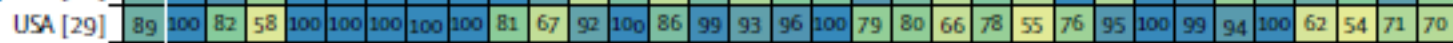

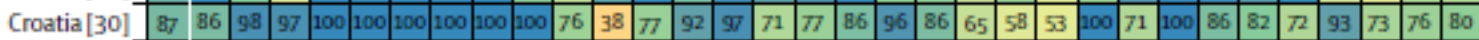

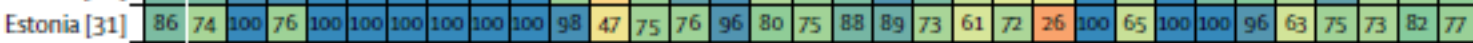

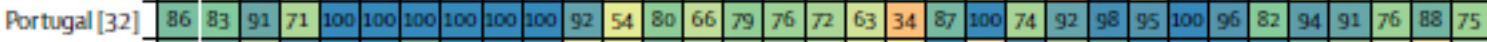

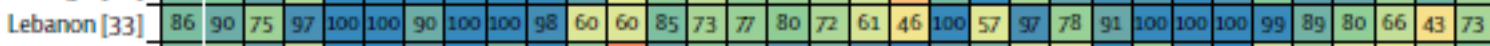

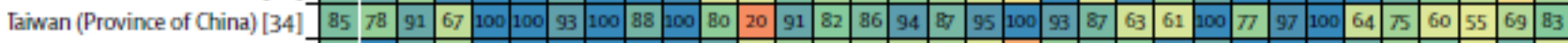

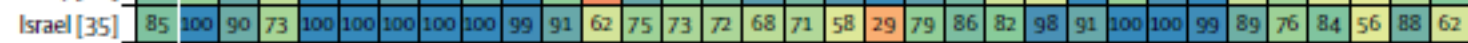

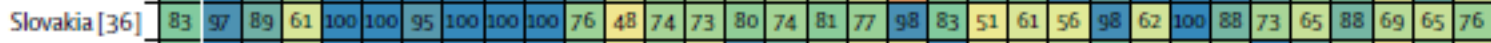

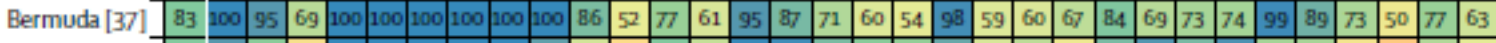

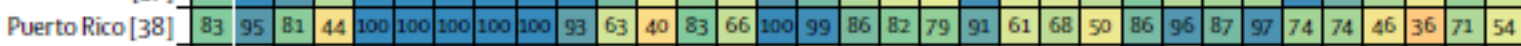

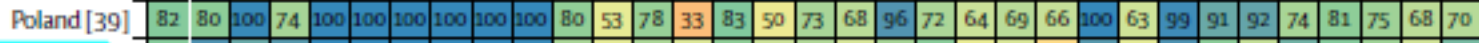

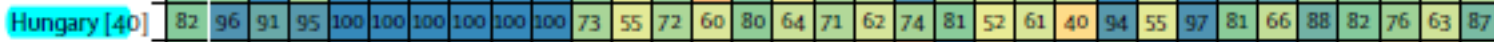

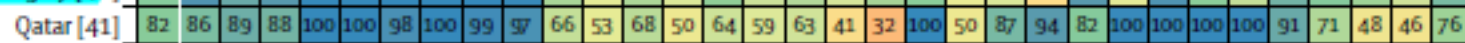

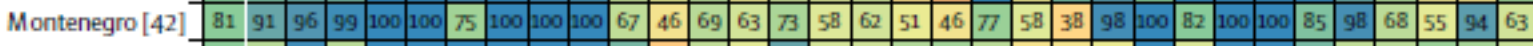

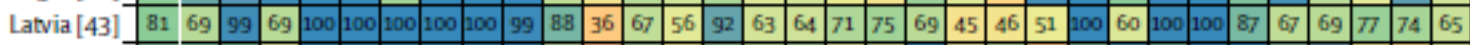

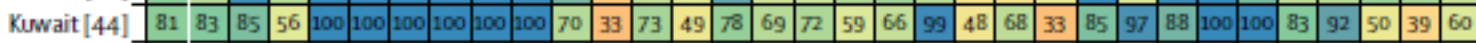

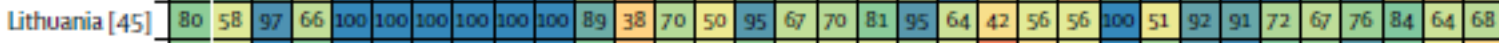

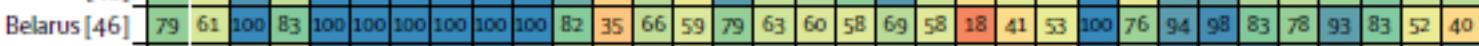
Romania [47]

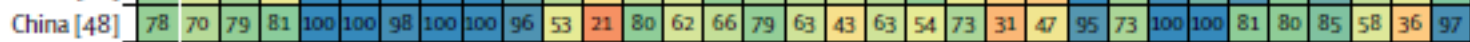
\begin{tabular}{|c|c|c|c|c|c|c|c|c|c|c|c|c|c|c|c|c|c|c|c|c|c|c|c|c|c|c|c|c|c|c|c|c|c|c|c|} 
Chile [49] & 78 & 74 & 93 & 70 & 100 & 100 & 92 & 100 & 100 & 88 & 66 & 39 & 75 & 69 & 72 & 66 & 71 & 51 & 40 & 79 & 92 & 69 & 64 & 88 & 90 & 89 & 75 & 65 & 76 & 88 & 52 & 58 & 77 \\
\hline
\end{tabular}

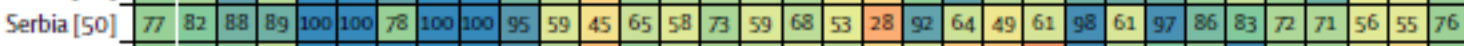

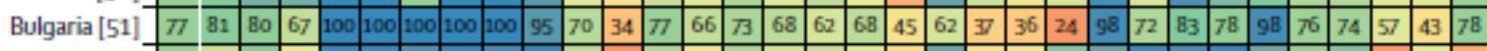

Forrás: GBD 2016 


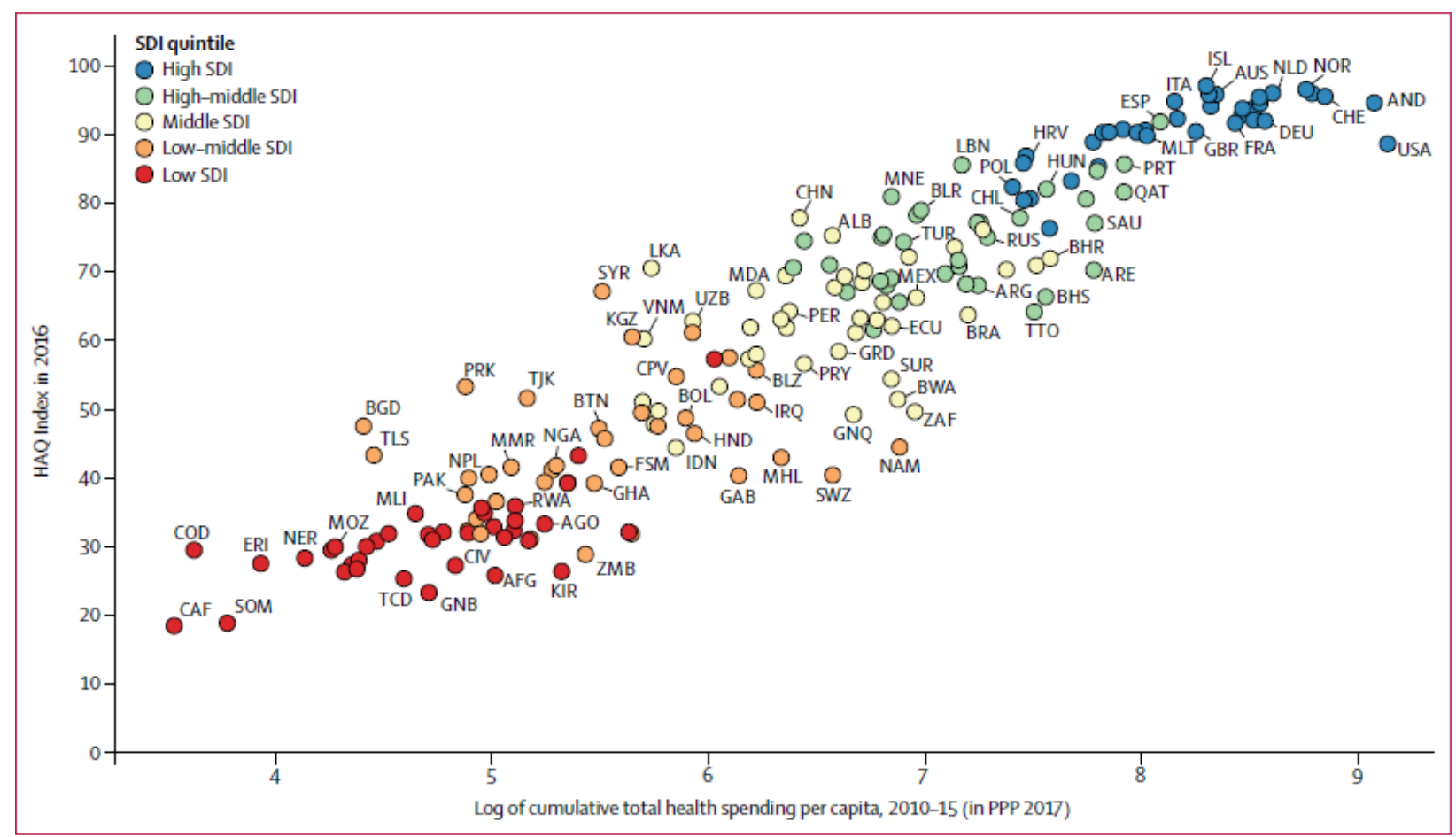

Forrás: GBD 2016

\section{MEGBESZÉLÉS}

Magyarországon az egészségügyi rendszer eredményességét főként halandósági adatokkal, kiemelten a várható élettartammal szokás jellemezni. új szakaszt nyitott azonban egy 2013-as miniszteri rendelet a hazai egészségügyi rendszer teljesítményértékeléséről.7 A 2016-ban megjelent első, nemzetközi gyakorlat szerint elkészített jelentésben ugyanis közel 100, az egészségügyet különböző szempontból jellemző mutató szerepelt. 8,9 Ezek között megjelent az EHMI alapját képező megelőzhető és elkerülhető halálozás is. Érdemes megjegyezni, hogy a megfelelő orvosi ellátással elkerülhető halálozást - mint az ellátás minőségi indikátorát - több mint 40 éve, már 1976-ban ajánlották, és az első magyarországi elemzés eredményeit már 1991-ben közreadták, de Magyarországon hivatalos dokumentumban több mint 25 évvel később, a 2016-os jelentésben közölték először ezt a mutatót. ${ }^{10,11}$

Az egészségügy eredményességének a megelőzhető és elkerülhető halálozással történő mérésében a GBV projekt nagy „újítása” az egészségügyi rendszeren kívüli tényezők hatásának kiszűrése.
A kockázati tényezők, illetve a rákhalálozás esetében az új esetek figyelembevételével tulajdonképpen azt érik el, hogy az egészségügy teljesítményét a megelőzési és ellátási szükségletekhez viszonyítják. Az egészségügyi ellátás igénybevételének szükségletre történő korrigálása már a 2000-es évek közepétől ismert eljárás, és Magyarországon is történtek ilyen vizsgálatok. $^{12,13}$ A szükséglet jövedelmi különbségeit kiszűrve például ki lehetett mutatni, hogy Magyarországon a kórházi ellátást inkább a magasabb jövedelmúek, míg az alapellátást az alacsonyabb jövedelmúek veszik igénybe - azonos ellátási szükséglet esetén. ${ }^{14} \mathrm{Az}$ EHMI a szükségletre korrigálás miatt az egészségügyi rendszerek eredményességére vonatkozóan az eddigieknél megbízhatóbb összevetési lehetőséget biztosít.

Az EHMI 2016-os értékei összességében megbízhatónak tűnnek, hiszen az országok és országrészek egymáshoz viszonyított helyzete összhangban van a korábban más módszerrel végzett értékelésekkel, az azokra épülő szakmai elvárásokkal. Így például a hazai egészségügy teljesítményét az élenjáró európai országokéhoz viszonyítva jelentősen javithatónak értékelte az EU Gazdasági-pénzügyi 
Főigazgatóságának egy 2015-ös elemzése. ${ }^{15}$ „Kifejezetten Csehország, Litvánia és Szlovákia mutatja a legalacsonyabb hatékonyságot a legtöbb vizsgált modell alapján. Magyarország, Lettország, Lengyelország és Észtország csak kicsivel jobbak, mint az előző csoport, de ugyancsak alacsony hatékonyságúak." - írják e tanulmányban a szerzők. Számításaik szerint Magyarországon az elkerülhető halálozás több mint 60\%-kal kisebb, a születéskor várható élettartam közel 4 évvel hosszabb lenne, ha a magyar egészségügyi rendszer hatékonysága az élenjárókéval megegyezne.

Talán a szakembereknek nem okozott meglepetést, hogy a GBV projekt elemzése is kimutatta, a magyarországi egészségügynek két területen igen rossz a teljesítménye: a keringési betegségek valamint a rosszindulatú daganatok megelőzése és gyógyítása területén. Hasonló következtetésre jut a hazai teljesítményértékelési jelentés „Kiemelt területek" című melléklete, amely szerint az egészségügyi rendszer céljainak elérése érdekében részletes vizsgálatot, esetleges beavatkozást indokol „,...a megelőzhető és elkerülhető halálozás magas értéke - különös tekintettel a korai halálozásra, a keringési rendszer betegségeire és a daganatokra" ${ }^{16}$

A magyar egészségügyi rendszer kedvezőtlen minősítéséhez minden bizonnyal hozzájárulnak a nem kielégítő inputjai is. A GBV projekt összefüggés-elemzésének eredményei szerint az alacsonyabb egészségügyi kiadások, valamint a magánkiadások magasabb részaránya az egészségügyi költségvetésben az ellátás rosszabb hozzáférésével és minőségével jár együtt. Valószínűsíthető, hogy ezek az összefüggések szerepet játszhatnak a hazai egészségügy gyengébb teljesítményében is. Ezt támasztja alá a Magyar Nemzeti Bank egyik elemzőjének a 2017-es tanulmányában tett megállapítása, miszerint: „....Magyarországon a közkiadások szintje elmarad, miközben a háztartások közvetlen egészségügyi kiadása meghaladja a nemzetközi és régiós átlagot." ${ }^{17}$

Végezetül érdemes végiggondolni, hogy a magyar egészségügyi rendszer teljesítményére vonatkozó adatok alapján milyen intézkedések vezethetnek eredményességének jelentős javításához. Célszerünek látszik az egészségre fordítható kormányzati költségvetést legalább a régiós átlag szintjéig növelni. Ez egyúttal a magánkiadások részarányának csökkenését is eredményezné, és e két változás önmagában is az egészségügyi szolgáltatásokhoz való jobb hozzáférést és az ellátás minőségének javulását hozná magával.

További pozitív előrelépés várható a hazai egészségügy erőforrásainak az elsődleges megelőzést előtérbe helyező átstrukturálásától, mert ahogy a GBV tanulmánya figyelmeztet, „az egészségügy kihívásai elviselhetetlenné válnak, ha a jelenlegi reaktív modelljét nem módosítja a proaktív múködés irányába”. ${ }^{4(2257.0 .)}$ Másképpen, „a hazai egészségügyi rendszer hatékonyságának növeléséhez a gyógyításról a megelőzésre szükséges nagyobb hangsúlyt helyezni, és ennek megfelelően a korábbinál több erőforrást biztosítani". ${ }^{18(11.0 .), i v}$ A megelőzhető és elkerülhető halálozási elemzések szerint a magyar egészségügyi rendszer optimális múködésével a 2015-ben elhunytak több mint harmada, a 65 évnél fiatalabbak háromnegyede maradt volna életben. ${ }^{19} \mathrm{Az}$ eredmények azt mutatják, hogy népegészségügyi beavatkozásokkal az orvosi ellátáshoz viszonyítva egyértelműen több életet lehetne megmenteni Magyarországon. A betegségekhez, illetve kockázati tényezőkhöz köthető egészségveszteségek, valamint a halandósági elemzések arra mutatnak, hogy az egészségügyi rendszer erőforrásainak célszerű átrendezése, különösen a népegészségügy megerősítése szükséges ahhoz, hogy a lakosság egészsége az ország társadalmi-gazdasági szintjén elvárhatót mielőbb elérje.

A nemzetközi tapasztalatok egyértelműen bizonyítják, hogy a hazai egészségügyi rendszer népegészségügyi szemléletű megújítása szükséges az eredményességhez, különösképpen a keringési rendszer és a rosszindulatú betegségek területén történő javításához, és ahhoz, hogy országunk az évente felállított EHMI világrangsorban előre léphessen.

\footnotetext{
iii A hazai egészségügyi rendszer megváltoztatásának szükségességéről és a lehetséges megoldásokról részletesebben lásd az Egészségjelentés 2016 Vezetői összefoglalóját!
} 


\section{HIVATKOZÁSOK}

\footnotetext{
${ }^{1}$ Global Burden of Disease (GBD) http://www.healthdata.org/gbd (Elérve: 2018. 08. 16.)

${ }^{2}$ Vitrai J, Varsányi P, Bakacs M. Új lehetőségek a magyarországi egészségveszteségek becslésére. LAM, 2015;25:283290.

${ }^{3}$ GBD 2015 Healthcare Access and Quality Collaborators. Healthcare Access and Quality Index based on mortality from causes amenable to personal health care in 195 countries and territories, 1990-2015: a novel analysis from the Global Burden of Disease Study 2015. Lancet, 2017;390(10091):231-266. doi: 10.1016/S0140-6736(17)30818-8.

${ }^{4}$ GBD 2016 Healthcare Access and Quality Collaborators. Measuring performance on the Healthcare Access and Quality Index for 195 countries and territories and selected subnational locations: a systematic analysis from the Global Burden of Disease Study 2016. Lancet. 2018;391(10136):2236-2271. doi: 10.1016/S0140-6736(18)30994-2

${ }^{5}$ Nolte E, McKee M. Measuring the health of nations: analysis of mortality amenable to health care. BMJ, 2003;327:1129-32. doi: 10.1136/bmj.327.7424.1129

${ }^{6}$ Amenable and preventable deaths statistics. Statistics Explained, Eurostat. http://ec.europa.eu/eurostat/statisticsexplained/index.php/Amenable and preventable deaths statistics (Elérve: 2018. 08. 16.)

${ }^{7}$ Az emberi erőforrások minisztere 36/2013. (V. 24.) EMMI rendelete az egészségügyi rendszer teljesítményértékelésének eljárásrendjére vonatkozó szabályokról

${ }^{8}$ Cylus J, Papanicolas I, Smith PC. (szerk.) Health system efficiency. How to make measurement matter for policy and management. World Health Organization, 2016.

${ }^{9}$ Egészségügyi Rendszer Teljesítményértékelési Munkacsoportja. A magyar egészségügyi rendszer teljesítményértékelése 2013-15. Állami Egészségügyi Ellátó Központ, Budapest, 2016. https://mertek.aeek.hu/web/mertek-magyaregeszsegugyi-rendszer-teljesitmenyertekelese/jelentes-2013-15 (Elérve: 2018. 08. 18.)

${ }^{10}$ Rutstein DD et al. Measuring the quality of medical care. N Engi Med 1976;294:582-8. doi: 10.1056/NEJM197603112941104

${ }^{11}$ Boján F, Vargáné Hajdú P, Belicza É. Avoidable mortality is it an indicator of quality of medical care in Eastern European countries? International Journal for Quality in Health Care, 1991;3:191-203. doi: 10.1093/intqhc/3.3.191

12 van Doorslaer E, Masseria C, Koolman X. OECD Health Equity Research Group: Inequalities in access to medical care by income in developed countries. CMAJ, 2006;174,177-183. doi: 10.1503/cmaj.050584

${ }^{13}$ Vitrai J, Bakacs M, Kaposvári Cs, Németh R. Szükségletre korrigált egészségügyi ellátás igénybevételének egyenlőtlenségei Magyarországon. LAM, 2010;20:527-532.

${ }^{14}$ Vitrai J. Egyenlőtlenségek az egészségügyi ellátás igénybevételében az ELEF adatai alapján. In: Európai lakossági egészségfelmérés - Tanulmányok III. Az egészségi állapot és az egészségügyi ellátórendszer. KSH, 2013, Budapest. 2140.

${ }^{15}$ Medeiros J, Schwierz C. Efficiency estimates of health care systems in the EU. Directorate-General for Economic and Financial Affairs, European Commission. 2015 Brüsszel.

${ }^{16}$ Egészségügyi Rendszer Teljesítményértékelési Munkacsoportja 2016. A magyar egészségügyi rendszer teljesítményértékelése 2013-15. Melléklet: Kiemelt területek. Állami Egészségügyi Ellátó Központ, Budapest https://mertek.aeek.hu/documents/68031/186704/17.Kiemelt+teruletek.pdf/f7b9e65c-a0f8-5aaf-1b9d-08c0860bab08 (Elérve 2018. 08. 18.)

${ }^{17}$ Asztalos P. A háztartások közvetlen hozzájárulása az egészségügyi kiadásokhoz Magyarországon. Statisztikai Szemle, 2017;95(8-9):873-900. doi: 10.20311/stat2017.08-09.hu0873

18 Bakacs M et al. Egészségjelentés 2016. Információk a népegészségügyi beavatkozások célterületeinek azonosításához a nem fertőző betegségek és az egészségmagatartási mutatók elemzése alapján. Szerk. Varsányi P, Vitrai J. Nemzeti Egészségfejlesztési Intézet, Budapest 2017.

${ }^{19}$ Vitrai J, Bakacs M, Varsányi P. Hazai egészség-pillanatkép, 2017. Egészségfejlesztés. 2017;58(4):59-75. doi: 10.24365/ef.v58i4.205
} 